堆 積 学 研 究, 58号, 57-63, 2004

J.Sed.Soc.Japan, No. 58，57-63， 2004

\title{
Uplift of Himalaya-Tibetan Plateau, evolution of East Asian monsoon, and sedimentation in East Asian marginal seas
}

\section{Ryuji Tada*}

Significance of the linkage between tectonics and climate is the long-lasting first order question in Geology that has never been answered clearly. The linkage between the uplift of Himalaya and Tibetan Plateau [HTP] and evolution of Asian-Indian monsoon has been regarded as the best example of tectonics-climate linkage because of its potential magnitude and importance with respect to global climatic evolution during the late Cenozoic. Although previous attempts failed to test this hypothesis because of the paucity and ambiguity of the tectonic and paleoclimatic data to constrain the timing and mode of both HTP uplift and monsoon evolution, the situation changes rapidly due to recent accumulation of tectonic data in HTP region and paleoclimatic data in inland Central and East Asia as well as continuous improvement in resolution and speed of climatic simulations.

In this synthesis, I will briefly summarize resent progress concerning our understanding on the timing and mode of the HTP uplift and the onset and evolution of the East Asian monsoon. I will then discuss potential significance of the linkage between the onset and evolution of millennial- to orbital-scale variability of Asian monsoon and the HTP uplift. Finally, I will demonstrate the significance of the impact of the HTP uplift and monsoon evolution on paleoceanography of the East Asian marginal seas.

Key words : Asian Monsoon, Himalaya-Tibetan Plateau, Land-Ocean Linkage, Marginal Sea Paleoceanography, Tectonics-Climate Linkage

\section{TECTONICS-CLIMATE LINKAGE IN EAST ASIA}

It has been argued that the uplift of Himalaya and Tibetan Plateau [HTP] exerted significant influence on the onset and evolution of AsianIndian monsoon based on GCM simulation results (e.g., Manabe and Terpstra, 1974 ; Kutzbach et al., 1989 ; Broccoli and Manabe, 1997). Although these simulation results provide us attractive hypotheses on monsoon evolution, they were difficult to be tested because the implica-

Received : November 4, 2003

* Department of Earth and Planetary Science, University of Tokyo

7-3-1 Hongo, Bunkyo-ku, Tokyo 113-0033, Japan tions derived from the simulations are too general and geological constraints on the monsoon evolution and HTP uplift are too sparse. However, these situations are quickly improved during the last 5 years.

For example, Liu and Yin (2002) examined the impact of the Tibetan Plateau uplift on evolution of the Asian monsoon and demonstrated that the evolution history could have been different between the Indian summer monsoon, East Asian summer monsoon, and East Asian winter monsoon. Namely, Indian monsoon should have been started and evolved by the uplift of Himalaya, and not so sensitive to the Tibetan Plateau uplift, whereas East Asian monsoon should have been more sensitive to the uplift of the Tibetan 
Plateau. Moreover, East Asian summer monsoon should have evolved during the early stage of the Tibetan Plateau uplift, whereas the East Asian winter monsoon should have evolved during the later stage of the uplift. Since the simulation results are more detailed and specific with respect to time and area, it becomes easier to test them based on the geological records.

Geological records on the HTP uplift also becomes more detailed during the last decade and stepwise evolution of the HTP becomes more evident (e.g., Copeland, 1997 ; Fig. 1). During the first stage of Indo-Asia collision $(40-25 \mathrm{Ma})$, tectonic escape seems to have been the principal mechanism that accommodated the strain caused by convergence of the two continents. Openings of the East Asian marginal seas such as South China Sea, Japan Sea, and Okhotsk Sea were most likely the results of the tectonic escape. During the second stage $(25-15 \mathrm{Ma})$, tectonic escape continued but the uplift of Himalaya started and became significant. Part of the southern Tibet was also uplifted. By $15 \mathrm{Ma}$, tectonic escape ceased. The third stage $(15-5 \mathrm{Ma})$ is characterized by continued uplift of Himalaya and southern Tibet. Probably, the uplift of Himalaya and southern Tibet culminated sometime during the late Miocene. The forth stage (5-0 Ma) is the period probably characterized by the uplift of the northern Tibet. Recent Chinese studies of northern and eastern Tibet demonstrate the occurrence of extensive conglomerate beds between 3.6 and $2.6 \mathrm{Ma}$ (e.g., Zheng et al., 2000), suggesting the uplift during these period. It is also worth to note that opening of Okinawa Trough and uplift of frontal Himalaya, Taiwan, and south to central Japan occurred during this stage (Sakai, 2002).

Geological records on East Asian monsoon and its evolution have also been accumulating rapidly. Most notable is the magnetic susceptibility of the loess-paleosol and red clay sequences in China, which demonstrates orbital-scale variability of East Asian summer monsoon during the last $8 \mathrm{Ma}$ (An et al., 2001). It is also considered that grain size (and flux) of loess is a good proxy for East Asian winter monsoon intensity (although it is possible that they are also influenced by intensity and position of the westerly jet). The Chinese loess record suggest that East Asian

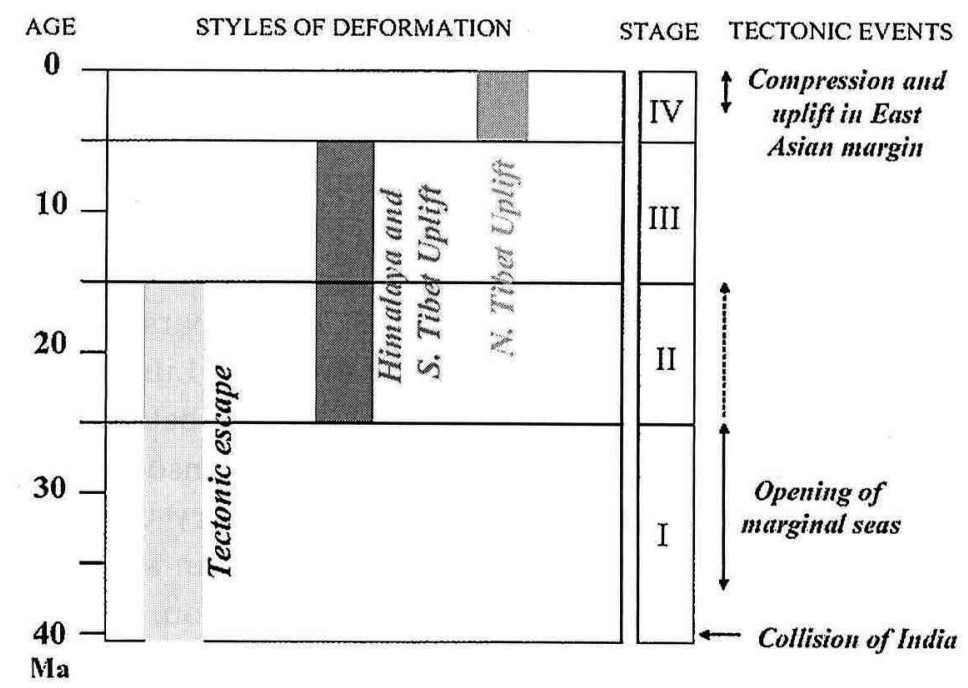

Fig. 1 Schematic diagram showing the temporal evolution of deformation styles and related geological events in association with the India-Asia collision and consequent uplift of Himalaya and Tibetan Plateau. 
monsoon was established by $8 \mathrm{Ma}$, both the summer and winter monsoon intensified and their variability increased between 3.6 and $2.5 \mathrm{Ma}$, the winter monsoon intensity continued to increase after $2.5 \mathrm{Ma}$, and the summer monsoon intensity decreased slightly after $2.5 \mathrm{Ma}$. Whereas Indian summer monsoon proxy record from Arabian Sea suggests its early onset and intensification approximately at 10-8 Ma.

Thus, the tectonic and paleoclimatic records described above tend to give the evidences concordant with the results of recent climatic simulations. However, the geological evidences are still insufficient especially with respect to spatial patterns of climatic changes to compare with the simulation results.

\section{ONSET OF THE MILLENNIAL-SCALE VARIABILITY OF ASIAN MONSOON AND UPLIFT OF THE TIBETAN PLATEAU}

Our study on the Japan Sea sediments demonstrates that organic deposition in the Quaternary Japan Sea varied significantly in association with the Dansgaard-Oeschger Cycles [DOC] (Fig. 2). DOC is millennial-scale abrupt climatic changes originally found in Greenland ice core record (GRIP Members, 1993). We interpret this millennial-scale variation in organic deposition in the Japan Sea as reflecting variation in the summer monsoon intensity and consequent changes in the Yangtze River discharge (Tada et al., 1999). Recently, a $\delta^{18} \mathrm{O}$ study of stalagmite in Chinese cave demonstrates that the East Asian

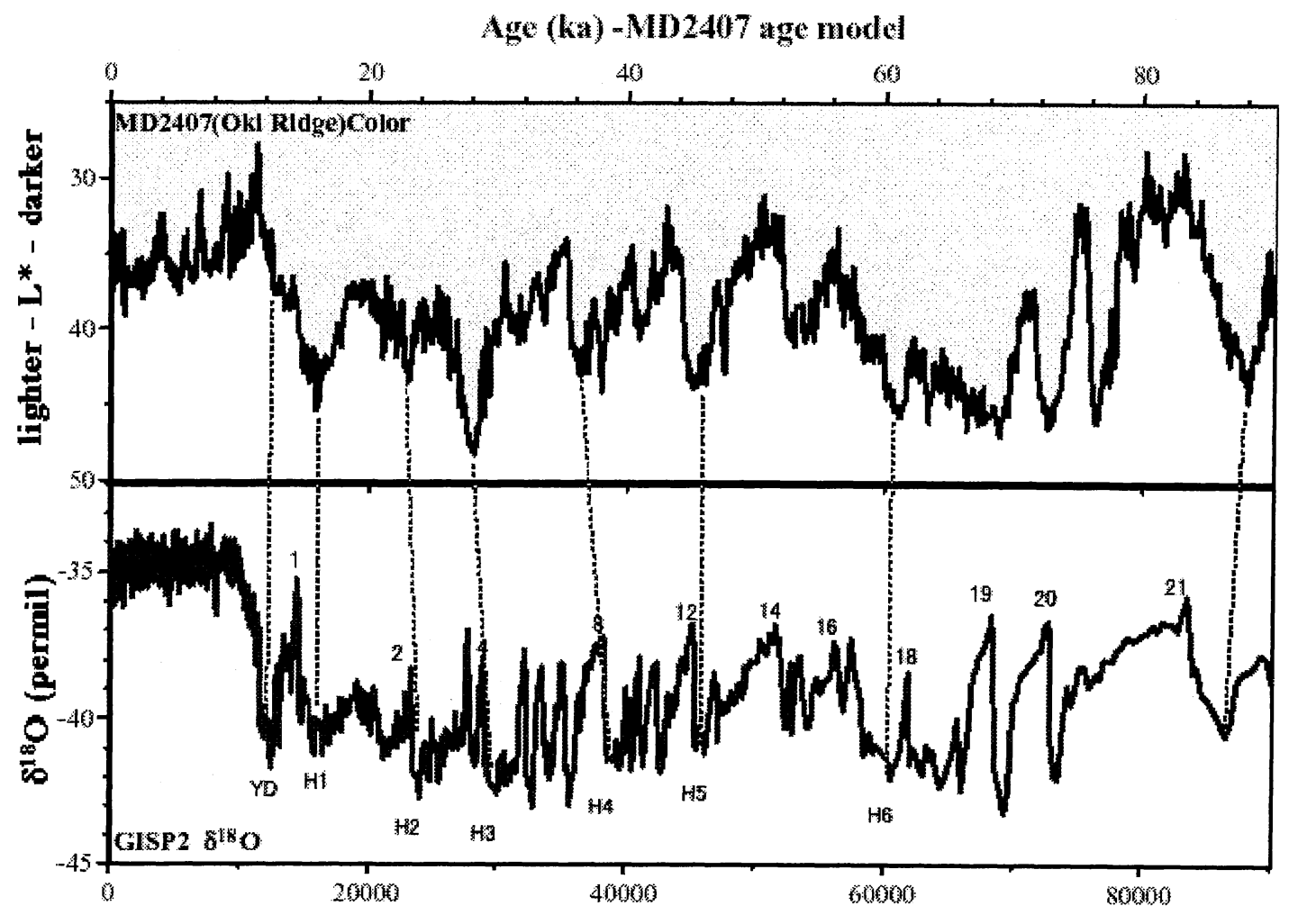

Age (y) BP) GISP2 age model

Fig. 2 Correlation of the gray scale $\left(L^{*}\right)$ of the late Quaternary hemipelagic sediments of the Japan Sea (MD01-2407 from Oki Ridge) with $\delta^{18} \mathrm{O}$ record of the GISP 2 ice core from central Greenland showing large and abrupt climatic oscillations known as the Dansgaard-Oeschger Cycles. It is interpreted that the dark layers reflect intensified periods of East Asian summer monsoon. 
summer monsoon intensity varied significantly in association with the DOC (Wang et al., 2001), which is consistent with our result. Eolian dust record in the Japan Sea sediments also suggests the linkage between the DOC and East Asian winter monsoon intensity or the position of the westerly jet (Nagashima et al., 2003). On the other hand, Schulz et al. (1997) demonstrated the association of the Indian summer monsoon with the DOC. Thus, it is now evident that Asian monsoon is closely linked with abrupt climatic changes in high latitude north Atlantic.

Although it is now well demonstrated that the DOC is a hemispheric phenomenon, their origin and propagation mechanism(s) are still controversial. Based on their multi-proxy study in the Mediterranean region, Sanchez-Goni et al. (2002) pointed out that the two atmospheric circulation modes were present corresponding to the stadials and interstadials of the DOC that could have been similar to the two atmospheric circulation modes of the North Atlantic Oscillation [NAO]. On the other hand, there are increasing evidences that East Asian winter and summer monsoon variability is strongly modulated by the Arctic Oscillation [AO] (e.g., Gong et al., 2001 ; Gong and Ho, 2003). Because it is generally accepted that NAO is a North Atlantic aspect of $\mathrm{AO}$, it is reasonable to consider that AO-type annular oscillation is the cause millennial-scale variability of Asian monsoon and possibley of the DOC itself. If this is the case, it is also possible that uplift of the HTP could have been the cause of the onset of the AO-type atmospheric oscillation, because stationary waves could be responsible for AO-type oscillation and uplift of the Tibetan Plateau strongly contributed the development of stationary waves (Broccoli and Manabe, 1997). This idea can be tested by examination of the evolution of the millennial-scale variability of the East Asian monsoon.

\section{MONSOON INFLUENCE ON SEDIMENTATION IN THE EAST ASIAN MARGINAL SEAS}

As is described above, our study demonstrates that the East Asian summer monsoon has a significant influence on the paleoceanographic condition of the Japan Sea through the Yangtze River discharge. It is evident that the Yangtze River (and to less extent the Huanghe River) has been the major source of the nutrient and freshwater to the Japan Sea except during the glacial maxima when the Tsushima Strait became nearly closed. The variations in freshwater and nutrient influx into the sea in response to the changes in the East Asian summer monsoon intensity drastically changed the surface productivity and bottom water ventilation in the Japan Sea. Surface productivity in the Japan Sea has been influenced both by the nutrient influx and the upwelling intensity (=ventilation rate) variations, and the way of its response seems different between glacial and interglacial periods. The bottom water oxygenation condition of the sea also varied significantly from hyperoxic $\left(\mathrm{O}_{2}\right.$ $>5 \mathrm{ml} / \mathrm{l})$ to euxinic $\left(\mathrm{H}_{2} \mathrm{~S}\right.$ present in the water column) in response to the changes in the monsoon intensity. The deepwater formation in the sea occurred as a result of winter cooling in the northwestern part of the sea, and it is possible that its rate is influenced by the strength of the winter monsoon. It is also demonstrated that there is a significant contribution of the ealian dust to the hemipelagic sediments in the Japan Sea and that it is possible to extract such information as eolian dust flux and its grain size (Irino and Tada, 2000, 2002).

Similar monsoon-ocean linkage is expected in other marginal seas. In case of the Okhotsk Sea, sea ice formation and consequent deposition of the ice-rafted debris could have been influenced by the winter monsoon, and intermediate water formation could have been influenced by summer monsoon, which modulated discharge of the Amur River. In case of the South China Sea, 
significant difference in surface salinity between the sea and immediately outside the sea in the northwestern Pacific is reported and suggested as reflecting the intensity of the summer monsoon. Thus, the sediments in the East Asian marginal seas contain abundant information on the onset and evolution of the East Asian monsoon.

\section{TECTONIC INFLUENCE ON THE SEDIMENTARY SYSTEMS OF THE EAST ASIAN MARGINAL SEAS}

If we want to reconstruct the onset and evolution of the East Asian monsoon using the sediments in the East Asian marginal seas, we have to take the temporal changes in the boundary conditions such as the changes in the basin geometry and the drainage patterns into account. Based on their detailed examination on drainage patterns in southeastern Tibet, Clark et al. (2003) suggest that the drastic changes in the drainage patterns occurred in Southeast Asia in response to the uplift of eastern Tibet sometime during the late Miocene. Their reconstruction suggests expansion of the Yangtze River drainage area by factor of ca. 2.5 in expense of the shrinkage of the Red River drainage area by factor of ca. 10 probably during the late Miocene. Such changes in the drainage pattern should have exerted significant influence on the freshwater, nutrient, and sediment delivery among the South China Sea, East China Sea, and the Japan Sea. Details of such changes can be examined only by ocean drilling. We also have to take the opening process of the Okinawa Trough into account when interpreting the paleoceanographic changes in the Japan Sea.

\section{SUMMARY}

In summary, it becomes increasingly evident that the uplift of Himalaya and Tibet Plateau exerts significant impact on the onset and evolution of the East Asian monsoon. It also becomes evident that evolution of the East Asian monsoon exerts significant impact on the sedimenta- tion and paleoceanography of the East Asian marginal seas. Although not described in detail here, feedback processes that exert influence from oceanography of the marginal seas to the terrestrial climate should also be present and could be significant. In such ways, tectonicsclimate as well as land-ocean linkages have been playing significant roles on the environment in East Asia and its marginal seas.

Integrated Ocean Drilling Program [IODP], the first large international geo-science program led by Japanese scientists, has just started from this year and now looking for the positive participation of Japanese and Asian geo-scientists. In this respect, international cooperation under the theme of tectonics-climate and land-ocean linkages in association with the HTP uplift and monsoon evolution will be timely and adequate to utilize and promote IODP.

\section{ACKNOWLEDGEMENTS}

I express my sincere thanks to Drs. Hoyanagi and Matsumoto who organized the opening symposium of the Sedimentological Society of Japan, and gives me an opportunity to write this synthesis. I also express my thanks to my students Fujine, Nagashima, Kido, Minami, and Watanabe who inspired me in various aspects through the discussion on their thesis works related to the Japan Sea paleoceanography.

\section{REFERENCES}

An, Z., Kutzbach, J.E., Prell, W.L. and Porter, S.C., 2001 : Evolution of Asian monsoons and phased uplift of the Himalaya-Tibetan plateau since Late Miocene times, $\mathrm{Na}$ ture, 411, 62-66.

Broccoli, A.J. and Manabe, S., 1997 : Mountains and midlatitude aridity. In Ruddiman, W.F., ed., Tectonic Uplift and Climate Change, Plenum Press, New York, 89-121.

Clark, M. K., Schoenbohm, L. M., Royden, L.H., Whipple, K.X., Burchfiel, B.C., Zhang, X., Tang, W., Wang, E. and Chen, L., 2003 (in press) : Surface uplift, tectonics, and erosion of Eastern Tibet from large-scale drainage patterns. Tectonics.

Copeland, P., 1997 : The when and where of the growth of the Himalaya and the Tibetan Plateau, In Ruddiman, W.F., ed., Tectonic Uplift and Climatic Change, Plenum, New 
York, 19-40.

Gong, D.Y. and Ho, C.H., 2003 : Arctic oscillation signals in the East Asian summer monsoon, J. Geophys. Res., 108 (D 2), 4066, doi : 10.1029/2002JD002193.

Gong, D.Y., Wang, S.W. and Zhu, J.H., 2001 : East Asian winter monsoon and Arctic Oscillation. Geophys. Res. Lett., 28, 2073-2076.

GRIP Members, 1993 : Climate instability during the last interglacial period recorded in the GRIP ice core, Nature, 364, 203-207.

Irino, T. and Tada, R., 2000 : Quantification of aeolian dust (Kosa) contribution to the Japan Sea sediments and its variation during the last $200 \mathrm{ky}$. Geochem. J., 34, 59-93.

Irino, T. and Tada, R., 2002 : High-resolution reconstruction of variation in aeolian dust (Kosa) deposition at ODP site 797, the Japan Sea, during the last $200 \mathrm{ka}$. Global and Planetary Change, 35, 143-156.

Kutzbach, J.E., Guetter, O.J., Ruddiman, W.F. and Prell, W. L., 1989 : Sensitivity of climate to late Cenozoic uplift in southern Asia and the American West : Numerical experiments. J. Geophys. Res., 94, 18393-18407.

Liu, X. and Yin, Z. Y., 2002 : Sensitivity of East Asian monsoon climate to the uplift of the Tibetan Plateau. Palaeogeogr., Palaeoclimatol., Palaeoecol., 183, 223-245.

Manabe, S. and Terpstra, T.B., 1974 : The effects of mountains on the general circulation of the atmosphere as identified by nummerical experiments. J. Atmos. Sci., 31, $3-41$.
Nagashima, K., Tada, R. and Matsui, H., in press : Variability of East Asian monsoon/westerly intensity during the last $140 \mathrm{ky}$ : A reconstruction based on Kosa grain size and content estimation in the Japan Sea sediments. Quat. Res., (in Japanese with English abstract).

Sakai, H., 2002 : Changes in depositional system of the PaleoKathmandu Lake caused by uplift of the Nepal Lesser Himalayas. Jour. Asian Earth -Sci., 20, 267-277.

Sanchez Goni, M.F., Cacho, I., Turon, J.-L., Guiot, J., Sierro, F. J., Peypouquet, J.-P., Grimalt, J.O. and Shackleton, N.J., 2002 : Synchroneity between marine and terrestrial responses to millennial scale climatic variability during the last glacial period in the Mediterranean region. $C l i$ mate Dynamics, 19, 95-105.

Schulz, H., von Rad, U. and Erlenkeuser, H., 1997 : Correlation between Arabian Sea and Greenland climate oscillations of the past 110,000 years. Nature, 393, 54-57.

Tada, R., Irino, T. and Koizumi, I., 1999 : Land-ocean linkage over orbital and millennial timescales recorded in late Quaternary sediments of the Japan Sea. Paleoceanography, 14, 236-247.

Wang, Y.J., Cheng, H., Edwards, R.L., An, Z.S., Wu, J.Y., Shen, C.C. and Dorale, J. A., 2001 : A high-resolution absolute-dated Late Pleistocene monsoon record from Hulu Cave, China. Science, 294, 2345-2348.

Zheng, H., Powell, C., An, Z., Zhou, J. and Dong, G., 2000 : Pliocene uplift of the northern Tibetan Plateau. Geology, 28, 715-718. 


\section{ヒマラヤチベット高原の隆起, 東アジアモンスーンの発達と 東アジア縁海における堆積作用}

多田 隆治, 2004, 堆積学研究, No. 58, 57-63

Tada, R., 2004 : Uplift of Himalaya-Tibetan Plateau, evolution of East Asian monsoon, and sedimentation in East Asian marginal seas.

Jour. Sed. Soc. Japan, No. 58, 57-63

構造運動々気候変動のリンケージがどのくらい重要な役割を果たしているかは, 地質学にお ける第一級の疑問であるにあ拘らず，未だ明確な答えが出されていない，特に，ヒマラヤ一チ ベット高原の隆起がアジアーインドモンスーンの強化を引き起こしたとする仮説は, その影響 の大きさ, 新生代後期の気候進化における重要性から, 構造運動一気候変動リンケージの代表 例とみなされている。これまでは，ヒマラヤ一チベット高原の隆起時期や様式，モンスーンの 出現時期や発達様式を制約する地質学的デー夕が不足し, また, 曖昧であったため, この仮説 を検証できずに現在に至った。 しかし, 近年, ヒマラヤーチベット高原地域の構造地質学的 データや東一中央アジア内陸部の古気候データが蓄積し, 気候シミュレーションの速度や解像 度が改善されるにつれて，この仮説を検証できる状況は，急速に整いつつある.

本総説においては, 先ず, ヒマラヤ一チベット高原の隆起時期や様式, アジアモンスーンの 出現時期や発達様式に関する理解の最近の進歩について簡単に紹介する. そして次に, 数千年 から数万年スケールでのアジアモンスーン変動の出現時期や発達様式とヒマラヤ一チベット高 原隆起の関係の重要性について議論し, 最後に, ヒマラヤーチベット高原の隆起やアジアモン スーンの発達が，東アジアの縁海に如何に大きな影響を与えてきたかについて紹介する. 